\title{
Traces of The Socialist in Exile: Mohammad Hatta and Sutan Sjahrir
}

\author{
Muhammad Farid ${ }^{*}$ \\ ${ }^{1}$ Lecture of Social Science, STKIP Hatta-Sjahrir, Banda Naira, Maluku Tengah, \\ Indonesia \\ Nusantara, Banda, Kabupaten Maluku Tengah, Maluku, Indonesia \\ Email: m.farid@hattasjahrir.ac.id
}

\begin{abstract}
This paper aims to reveal the traces of the two national figures, Mohammad Hatta and Sutan Sjahrir during exile in Banda Naira. Both are warrior figures that are difficult to forget in the history of the nation. But their popularity was barely revealed during their exile in Banda Naira. In fact, the legacy of their thoughts and role models is needed to respond to the crisis of leaders who have morality and integrity for Indonesia, and at the same time respond to the challenges of the global era. This paper based on the results of qualitative-historical research, using a phenomenological perspective, especially on the narratives of everyday life of Hatta and Sjahrir in exile Banda. The results of this study indicate that Hatta and Sjahrir were both patriots and educators even they were far away in exile. They built an "Kelas Sore" for Banda children, teaching the values of everyday life, including; religious-ethics, self-integrity, and nationalism. These values are become valuable exemplary for todays young generation, and especially for the people of Banda Naira. This paper concludes, that Hatta and Sjahrir are the most consistent socialist role models in struggling and educating the people for sovereignty, and for a truly independent Indonesian nation.
\end{abstract}

Keywords: religious-ethics, self-integrity, nationalism

\begin{abstract}
Abstrak
Tulisan ini bertujuan untuk mengungkap jejak-jejak kedua tokoh bangsa, Mohammad Hatta dan Sutan Sjahrir selama di pengasingan Banda Naira. Keduanya adalah sosok pejuang yang sulit dilupakan dalam sejarah bangsa. Namun popularitas mereka nyaris tidak terungkap selama di pengasingan Banda Naira. Padahal, warisan pemikiran dan teladan sikap mereka sangatlah dibutuhkan untuk menjawab krisis pemimpin yang bermoral dan berintegritas bagi Indonesia, dan sekaligus menjawab tantangan zaman global. Tulisan ini berdasarkan hasil penelitian kualitatif-historis, dengan menggunakan perspektif fenomenologis khususnya terhadap narasi kehidupan sehari-hari Hatta dan Sjahrir di pengasingan Banda. Hasil penelitian ini menunjukkan bahwa Hatta dan Sjahrir adalah pejuang sekaligus pendidik sekalipun mereka berada jauh di pengasingan. Mereka membangun "sekolah sore" untuk anak-anak Banda, mengajarkan nilai-nilai kehidupan sehari-hari; meliputi etika-religius, integritas-diri, dan nasionalisme. Nilainilai itu menjadi teladan bagi generasi muda hari ini, dan khususnya bagi masyarakat Banda Naira. Tulisan ini menyimpulkan, bahwa Hatta dan Sjahrir adalah sosok teladan sosialis yang paling konsisten dalam berjuang dan mendidik rakyat demi kedaulatan, dan demi bangsa Indonesia yang benar-benar merdeka.
\end{abstract}

Kata Kunci: etika-religius, integritas-diri, nasionalisme 


\section{INTRODUCTION}

The political biography of Mohammad Hatta is his personal mirror that lives in a strong religious tradition on the one hand, and modernism of Islamic thought on the other. Hatta's father, Muhammad Djamil, was the son of Sheikh Abdurrahman, a great cleric caretaker of the Naqsabandiyah Order in Payakumbuh, West Sumatra. Hatta's mother, Siti Salehah, was the daughter of Ilsyah Bagindo Marah, A one big trader who owned postal services in the colonial period (Hatta 2011).

Unlike Hatta with a religious family background, Sutan Sjahrir was born to a very modern family of his father. Sjahrir's father, Muhammad Rasyad Maharajo Sutan, is a trader from the City of Gadang. While his mother, Siti Rabiah, came from Mandailing Natal, North Sumatra. Sjahrir's father has six wives. Siti Rabiah is the fifth. According to historian Mestika Zed, the modern intellectual horizon of Sjahrir was strengthened by intelligence since childhood. This show that religious-based ideological cleavage through decades of authoritarianism and democratic politics characterized by ideological moderation (Fossatia, Aspinallb, Muhtadic, and Warburtond 2020).

Hatta and Sjahrir's thoughts increasingly developed in the Netherlands. Hatta experienced significant maturity when he continued his studies in the Netherlands. Hatta studied many major world ideologies such as socialism, marxism, capitalism there. In addition to being active in a number of discussion organizations and societies, Hatta was also very productive in introducing ideas through his critical writings to the heart of colonial rule. In one of his criticisms, Hatta said that, "the struggle for Indonesian independence is at the same time a struggle for democracy and universal humanity. And the achievement of democracy and humanity in the struggle was a matter of the transfer of power from the colonial government to the people of Indonesia " (Rose 2010).

Sutan Sjahrir is also a critical activist who prioritizes understanding rather than just memorizing lessons. According to his friend Salomon Tas, the young Sjahrir had mastered Latin, studied philosophy, and the history of the ancient Roman empire. Sjahrir loved political debates with the study group Patriae Scientiaeque, one of the most popular communities in the Netherlands (Anwar 2011). Sjahrir attended the Law School of Gemeente Universitiet van Amsterdam and then enrolled again at Leiden Universiteit. But he rarely follows lectures. His 
Farid: Traces of The Socialist in Exile:

Mohammad Hatta And Sutan Sjahrir

interest and attention were instead absorbed by the ideas of Socialism, as a result of the European Zeitgeist after World War I, namely Marxism which always fostered the spirit of fighting to improve the lot of the workers exploited by capitalism. Sjahrir's most favorite slogan at the time was "Proletarians all over the world, unite!"

To sharpen its Socialist ideology, Sjahrir looking for extreme left-wing radical friends who firmly refused everything that smelled of capitalism. He also worked at the secretariat of the International Transport Labor Federation. During a search for radical friends, Sjahrir met Hatta, who was studying at the School of Economics in the city of Rotterdam. At that time, Hatta was the chairman of the Indonesian Association of Society (PI) which was founded in 1908. Sjahrir then joined and was elected as a secretary of the PI, right in February 1930, when he was still 21 years old.

Hatta and Sjahrir's thoughts were increasingly popular. Both were multidimensional figures; warrior and thinker; scientists as well as activists. In the colonial period, they participated in coloring the character of Indische Vereeniging, an Indies student association which was initially more social in nature and then turned into a political movement of resistance. Hatta, Sjahrir and his friends even became the first youth group to introduce the word "Indonesia" in a geopolitical sense, by changing the name from Indische to Indonesisch Vereeniging or the Indonesian Association. Later, this organ transformed more progressively under the name, "Free Indonesia".

Both are increasingly widely known in the arena of international politics. Hatta was the first Indonesian to collaborate with an intellectual and movement figure, Jawaharlal Nehru, from India. Like Hatta, Nehru also rejected the ideology of communism that used violent methods to legitimize power as practiced by the dictators of the Soviet Union. Both prefer to support the political path of cooperation in a non-violent way. The political ideology may play a role in a cooperation (Chan and Ilicic 2019). For Hatta and Nehru, they agreed to respect the invaders as human beings, but remained critical of the practice of colonialism which was fatal and destructive.

Both are increasingly widely known in the international political arena. And for the first time an Indonesian collaborated with Jawaharlal Nehru from India. 
Like Hatta, Nehru also rejected the ideology of communism which used violent methods for the legitimacy of power practiced by the dictator of the Soviet Union. Both of them also support a non-violence political cooperation. For Hatta and Nehru, they agreed to respect invaders as humans, but remained crtical of the practice of colonialism which had a fatal and destructive impact (El-Torky 2018).

The situation changed in 1934, amid an atmosphere of political repression that made Governor General De Jonge make the decision to arrest 13 PNIPendidikan activists. Hatta finally taken to Glodok prison, and and Sjahrir was detained in Cipinang-Batavia prison. On January 23, 1935, they were both exiled to Boven Digul, where political prisoners who opposed the Dutch East Indies government (Bijl 2017). They were exiled for one year in the middle of a fierce forest, a river full of crocodiles, and the diseased area, which eventually made them both suffer from malaria.

In Digul-Papua, the conditions of Hatta and Sjahrir are getting weaker. This situation was finally known to the public which then triggered a reaction in the Indies and the Netherlands. Prime Minister Colijn in his statement at Tweede Kamer stressed that Hatta's exile in Papua was not aimed at destroying him, but rather to distance him from the wider community. In November 1935, the Dutch government finally officially moved Hatta from Digul-Papua to Banda NairaMaluku, a small island of 7000 inhabitants in the Banda Sea (Bijl 2017).

Novelty of this research is the discovery of the traces of the two national figures, Mohammad Hatta and Sutan Sjahrir during exile in Banda Naira.Amid a crisis of moral and integrity national figures, it is natural that many Indonesians still remember the traces of thoughts and examples of Mohammad Hatta and Sutan Sjahrir. Their thoughts seemed to continue to live in response to the challenges of the globalizing world. So the exemplary of Hatta and Sjahrir's thoughts and attitudes need to be constantly echoed to become an oasis for a better Indonesian civilization. For this purpose, this paper becomes important, which aims to reveal the exemplary and educational traces of two socialist figures in exile in Banda Naira, especially those relating to values; (1) religious ethics, (2) self-integrity, and (3) nationalism, which they had perpetuated during Banda's exile, and which is inherited to this day. 


\section{METHODS}

This paper is compiled based on the results of historical research using phenomenology perspective, adopting the key concepts of Alfred Shutz such as meaning, the lifeworld, stock of knowledge, typification, and others as a framework for study. Phenomenology is a philosophy as well as a method, which has a very broad impact on the type of qualitative research. As a method, phenomenology has been adopted by researchers from various scientific disciplines and social science fields who utilize their philosophical analysis. In addition to using textbooks, this paper also takes data sources from interviews with experienced subjects, including stories and diaries of individuals in Banda. There were 3 key informants; (1) the grandson of Hatta's adopted children, (2) the grandchildren of Hatta and Sjahrir's local friends while in exile, (3) some close friends of Des Alwi. The analysis focused on the phenomena of everyday life of Hatta and Sjahrir during exile in Banda, including relationships, friendship, and brotherhood that existed between.

In a phenomenological frame, phenomena are not understood like general definitions such as; natural phenomenon; extraordinary event; miracle; fact; reality; unforgettable event, however, the phenomenon as an event of everyday life. Edmund Husserl called it lebenswelt, Alfred Schutz termed life-world, Erving Gofman with everyday life. The events of everyday life at the same time emphasize that there are no small events that are not meaningful. Every spark of daily life is the main and the foundation of meaning (Borng 2002).

Why is Phenomenology important? Because only through a phenomenological approach will be found a complete and authentic understanding of an experience of everyday life. The philosophy of Phenomenology itself generally aimed to study human phenomenon without questioning its causes, where "life-world is principally the basic meaning which has been forgotten by science". The phenomenologist ordained for zurück zu de Sachen selbst or to the things themselves, or command to rediscover the authentic life-world.

Alfred Schutz, one of the theorists of this subject, emphasizes on individual aspects because the life-world is the world of man with conscious experience of cognitive actions and perception, and method to gain value or aesthetically 
appreciated. To Schutz, social reality is basically enfolded with subjective individual experience (Murphy 1986).

Existing social realities within individual's conscience deliver us to popular ideas stated by Schutz regarding stock of knowledge and typification. The stock of knowledge is a set of rules, social action recipe, proper behavior, and other knowledge, which later functioned as the basis reference of actions in the social world. From this stock of knowledge, individuals portray the reference outline or orientation, which enabled them to interpret ongoing occurrence in their life.

Thus, typification is a process of forming types of understandings and behaviors to simplify meaning and actions. However, typification is not merely about perception and behavior but also about meaning observation. From this process of typification, a human common sense is generated through language communication and social interaction which creates a sort of system of a relevance of togetherness.

By utilizing typification, direct knowledge from others is easier to be recognized and in turn, making establishing relation easier, which Schutz called as "contemporaries", "predecessors", and "successors", or those who never have experienced togetherness. The relations established may as well be direct (face to face) or indirect, as what the contemporaries may have but never been encountered, or with the ancestors and predecessors. This is shown for individual goals, whose inclusion via the recommended concepts of typification and relevance is suggested (Straßheim 2010).

\section{RESULTS AND DISCUSSION}

Historian generally do not record what happened after Hatta and Sjahrir were moved from Digoel-Papua. The only reference that is responsible for this matter only comes from the books written by Des Alwi, entitled Bersama Hatta, Sjahrir Tjipto, dan Iwa Kusuma di Banda Naira (2002), also Sejarah Banda Naira (2006), and Friend and Exiles (2016). Another works that record the exile of Banda was also written by Hatta himself in his biography entitled, Untuk Negeriku (2011), and Sjahrir, Out of Exile (1949).

In Des books, mentioned that Oom Hatta and Oom Sjahrir (as they were called) were in Banda Naira around February 1936. Both arrived in a boat named Fommel Haut, with a pale face. According to Des, the Banda people generally 
Farid: Traces of The Socialist in Exile:

immediately assumed that the masters who got off the ship must have been from Digul-Papua, because of the pale face caused by malaria (Alwi 2006).

In Hatta's biography, he wrote of their journey from Digul to Banda, and when they arrived at Banda they were anchored on a bridge near Banda's Gezaghebber's house. There they were picked up by someone from Mr. Iwa, and Dr. Tjipto adopted children (Anwar 2011). Mr. Iwa and Dr. Tjipto were two national figures who were exiled earlier than Hatta and Sjahrir.

While in Sjahrir's book, Out of Exile, Banda has been described as very beautiful and pleasant, even though inside his writings, Sjahrir could not hide his loneliness because it was far from his lover Maria. Out of Exile is a small book which is a collection of Sjahrir's letters to Maria since his arrest in 1934 - 1942. Even though it was only a collection of private letters, this book reveals many broader themes than the political situation of the Dutch East Indies or Europe. There were themes such as philosophy and culture which at that time were still popular in the West. This book more like a philosophical booklet.

During in Banda exile, Hatta and Sjahrir's condition was much better than in Digul-Papua. They don't even feel abandoned. They enjoy the comfortable nature. they were also allowed to interact freely with the people. But Hatta and Sjahrir were very concerned to see many children of Banda who were not educated.

Hatta and Sjahrir then planned to open a school for indigenous children. The school is known as Sekolah Sore (Afternoon School), which located behind Hatta's house which is next to the Dutch school. Hatta's house is a former house owned by a Dutch Perkenier. The size is very large, has three doors on the front porch, with traditional ornament made of wood (See picture 1). There are four rooms in the middle, and a very spacious back porch. This house is located in the center of the city of Naira. 
Figure 1

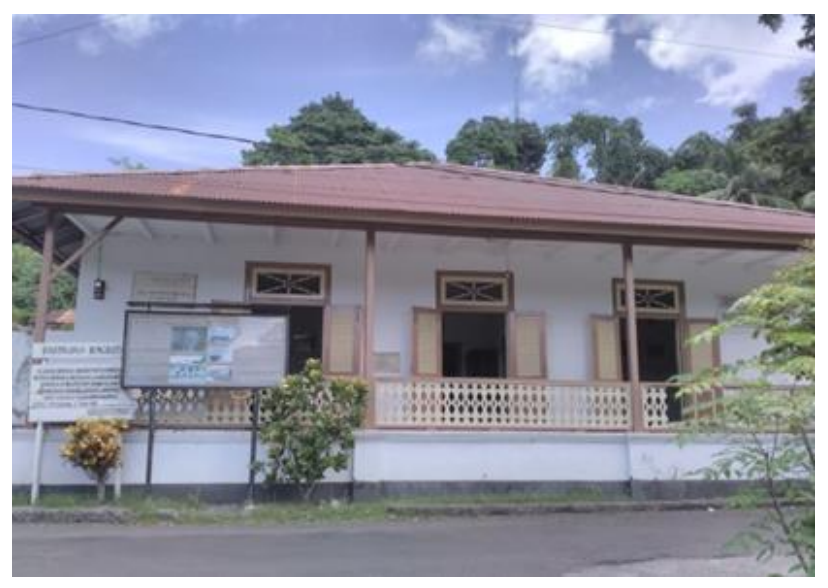

House of Mohammad Hatta in Banda Naira

Des Alwi was one of Hatta's students at that time. Hatta was called as $\mathrm{Om}$ Kacamata, while Sjahrir as Om Rir. Named Kelas Sore because it was held only in the afternoon on the back porch of Hatta's house (Hatta 2011).

Allmost all students of Sekolah Sore are Banda residents from lower and middle classes. Most of them are grandchildren of Baadilla, one of the largest clans in Banda. But there are also some children of political figures who were banished in Banda, such as Donald and Louis who are adopted children of Tjipto Mangunkusumo. Some of the other students were children of the masters of pearl transport ships, children of administrators of several nutmeg plantations, and several Banda children who had no chance to continue their education in Ambon, Makassar and Java.

Sekolah Sore are very simple school. The classroom is located on the back porch of the house. In the class there are only 7 wooden tables complete with chairs, and 1 black board (see figure 2). Hatta and Sjahrir shared their teaching assignments. Hatta gave lessons to older children, while Sutan Sjahrir taught smaller children. Hatta teaches; reading, writing, arithmetic and German language. All the lessons were given by Hatta in Dutch. At that time, Hatta had shown the importance of foreign languages, especially the Dutch, for the children to reach more advanced ideals of knowledge (Miller 2010). Therefore, Hatta also opened a private Dutch language for Banda Naira children who did not get the opportunity to enter European Elementary School. 
Figure 2

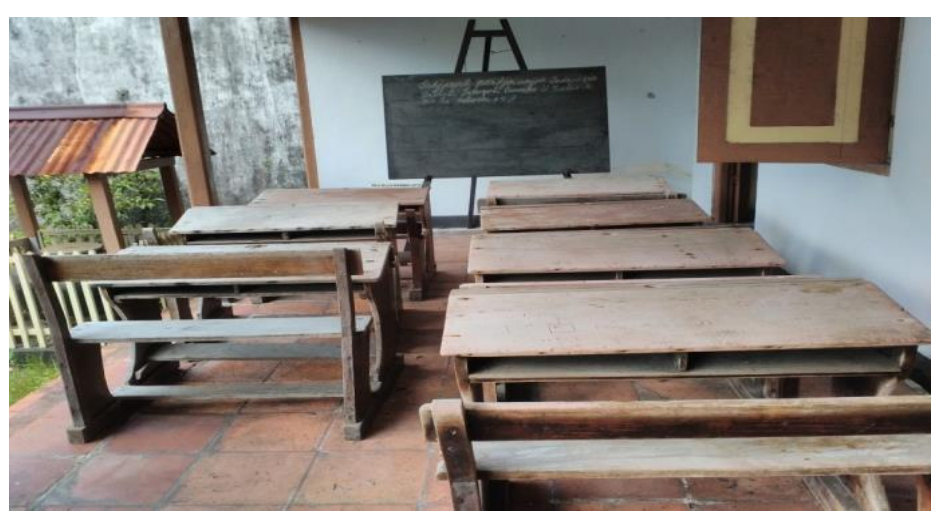

One of the clasroom of "Kelas Sore" in Banda Naira

Meanwhile, Sjahrir taught Dutch and counted for smaller students. Sjahrir was very concerned about foreign languages, because some Banda youths could not speak Dutch, which, according to Sjahrir, was very important to be able to continue to secondary school. In fact, Dutch is not familiar even to "Burgo" (Dutch-Banda residents) who prefer to speak Banda rather than the language of their ancestors (Alwi 2006).

Religious-Etics. According to the Oxford Dictionary, ethics is defined as: (1) a system of moral principles by which human actions can be judged as good or bad, right or wrong; (2) rules of behavior that are recognized with respect to certain classes of human action. From an Islamic point of view, ethics is related to several Arabic terms. These terms are as follows: ma'ruf (agreed), khayr (goodness), haqq (truth), birr (truth), qist (justice), 'adl (balance and justice), and taqwa (piety) (Al-Aidaros, Shamsudin, and Idris 2013). In the frame of Western ideology, ethical principles are very dependent on individual considerations in defining what is right and wrong (Veer 2003). Unlike the principles and values in Islam which all refer to Islamic sources (Mohammed 2011). Ethics in the Quran is called akhlaq, which is a set of actions covering all aspects of life, which is worthy of Islamic Worship, and is carried out as obedience to Allah's command to gain His acceptance.

The religiosity of Hatta and Sjahrir appeared in their daily lives. In Banda Naira, Hatta and Sjahrir often visited the homes of fellow political prisoners, such as Tjipto Mangunkusumo and Iwa Kusuma Sumantri. They were often involved in discussions with other Syarekat Islam figures who were also exiled in Banda 
Naira. Hatta's house was closer to Iwa Kusuma's house than Tjipto's. Its only about 700 meters from Hatta's. Iwa's house is also quite extensive and has a classic architecture like Hatta's house (see picture 3). In the Iwa house they discussed more about religion (Alwi 2002). Iwa Kusuma himself learned a lot about Arabic, Qur'anic interpretation and Islamic history from an Arab-Banda surnamed Bahlawan. Meanwhile Hatta, Sjahrir, Iwa and Tipto learned Arabic history from Mr. Bahlawan (Anwar 2011)

Figure 3

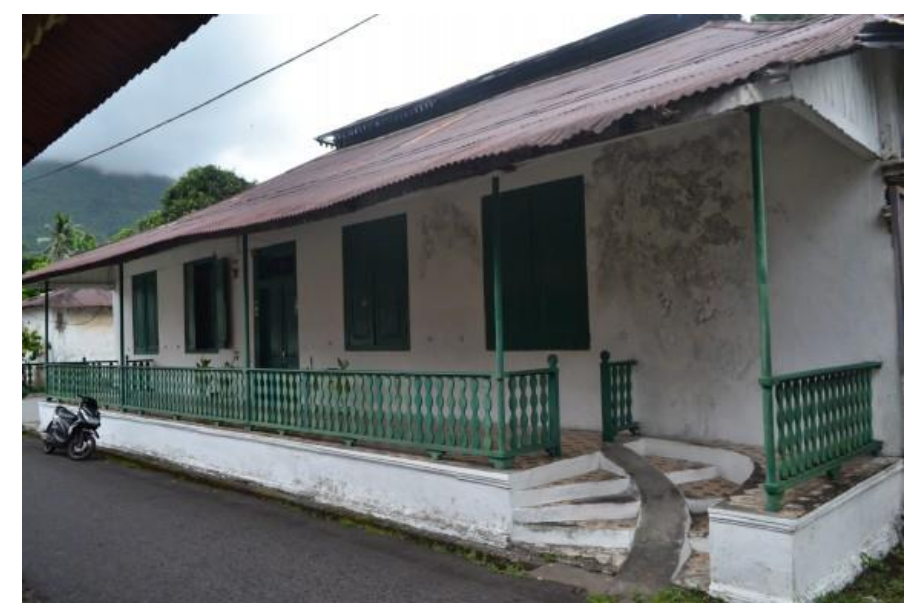

House of Iwa Kusuma Sumantri in Banda Naira

Hatta received religious education since childhood from Sheikh Abdurrahman, his grandfather who a great cleric of Naqsabandiyah in West Sumatra. Hatta's observance was maintained until he grows up adult. In Banda exile, worship was one of Hatta's routines that was never abandoned. In his biography, Hatta wrote, "I woke up in the morning at 5. I began to take a shower and continued to pray until 6 at a little. From 6 to 7 I read while drinking coffee. At 7 to 8 , according to the agreement with Sjahrir, we eat breakfast while chatting about various things (Hatta 2011).

Meanwhile, Sjahrir did not look as religious as Hatta. In fact he is often called "Westernized" by Hatta in front of the children. The label was mocked, as if Sjahrir was "lacking in piety", or "lacking in eastern wisdom". But Sjahrir did not want to lose then respond Hatta by saying; "Hatta moreover, even in dreams he uses Dutch!" (Alwi 2006).

Despite the different colors of religiosity, Hatta and Sjahrir share a common ethical principle, namely their attention to children's study time rather than religious study time. As Des Alwi said, Hatta and Sjahrir always provided an 
Farid: Traces of The Socialist in Exile:

Mohammad Hatta And Sutan Sjahrir

empty week to study the Koran at Haji Nyong, an Imam at the Kampung Baru Mosque. But if there is a class exam in a Dutch school, Hatta suggests to stop Islamic religious studies first until the exam is finished so that children do not feel hard (Alwi 2006)

Hatta in particular, had a humble attitude that was shown by refusing to be remembered through a statue monument or the like, as was customary in colonial times. Hatta even firmly forbade Des Alwi not to make a statue of himself. Hatta advised, if they wanted to remember him, then build a mosque for the people of Banda to be more useful (Alwi 2006)

While Sutan Sjahrir, is a figure who is very concerned about the fate of the poor who are legally problematic. In Banda, Sjahrir was even dubbed "pokrol bambu", meaning legal advisor for the poor. Since then, Sjahrir has been a conversation among the Banda people as a figure of a young man who is willing to give advice in matters concerning land, trade, debts for free (Anwar 2011). Sjahrir's partiality in defending the truth and goodness for the fate of the citizens is in line with the principle of khair (goodness) and the principle of haqq (truth) in the terminology of religious-ethics.

It seems clear that Hatta and Sjahrir have a kind of "rules of play" in their lives, which makes their daily life very organized and disciplined. Both also show a just and balanced attitude for spiritual and worldly life, caring for the destinies of the poor and needy. Such is the example of Hatta's religious-ethics example in their everyday lives. The ethnic and religious identities as well as the strength of individual religiosity and fundamentalism affect individual (Chuaha, Hoffmanna, Ramasamy, and Tan 2014). Also, Ethnicity appears to mediate the effects of education on religious trust (Kuenzi 2018).

Self-integrity. Integrity comes from the Latin that is integrity which means "as whole and represented completeness", or "something that shows the whole and completeness"; a whole of certain parts (Akira and Malie 2012). In the most recent Merriam-Webster Dictionary, integrity is defined as strong adherence to a code, specifically moral values or certain artistic values (Gea 2016).

Millard Fuller (2001) described integrity as "consistency in what is considered right and wrong in your life". While Shelly Lazarus (chairman and 
CEO of Ogilvy Mather Worldwide) explained that someone who has integrity is "putting forward a series of beliefs and then acting on principles" (Harisa 2011).

In Banda exile, Hatta likes routine and regular life. A routine includes the meaning of "consistency", or strong observance of a principle. According to Des 2006, Hatta's everyday life in Banda Naira is always well-dressed; wearing a clean white shirt with long sleeves and white trousers. He always gets up early at around 6:00. Usually he starts the day by shaving in front of a small mirror placed on the dining table and a warm water cup and shaving soap nearby. After shaving, Hatta took a bath for about half an hour. After taking a shower, Hatta sat on the back porch of his house enjoying his thick coffee while waiting for Sjahrir to have breakfast together. After breakfast, Hatta went straight into his room to read or write (Alwi 2006).

Hatta's routine made him dubbed Bandanese as a "walking hour". Des once told me (the author) the habit of Hatta walking around the city of Naira in the afternoon; starting from his house to the port then tracing the nutmeg plantation owned by the Dutch family at Pante Kasteng, then circling the hill behind the Belgica fortress, and returning to his house (Anwar 2011). Hatta's routins passing by villages and nutmeg plantations make him called "a walking clock". This means that wherever and whenever Hatta crosses in a particular road, the villagers can ensure that the clock has shown a certain hour.

Sjahrir also has the same routine. Sjahrir also has the same routine. When they were still living in one house Sjahrir had an agreement with Hatta to meet every day at 7 to 8 for breakfast and talk. After that, they separated for their personal work, and only met again at 1 to 2 to eat midday (Anwar 2011). 
Figure 4

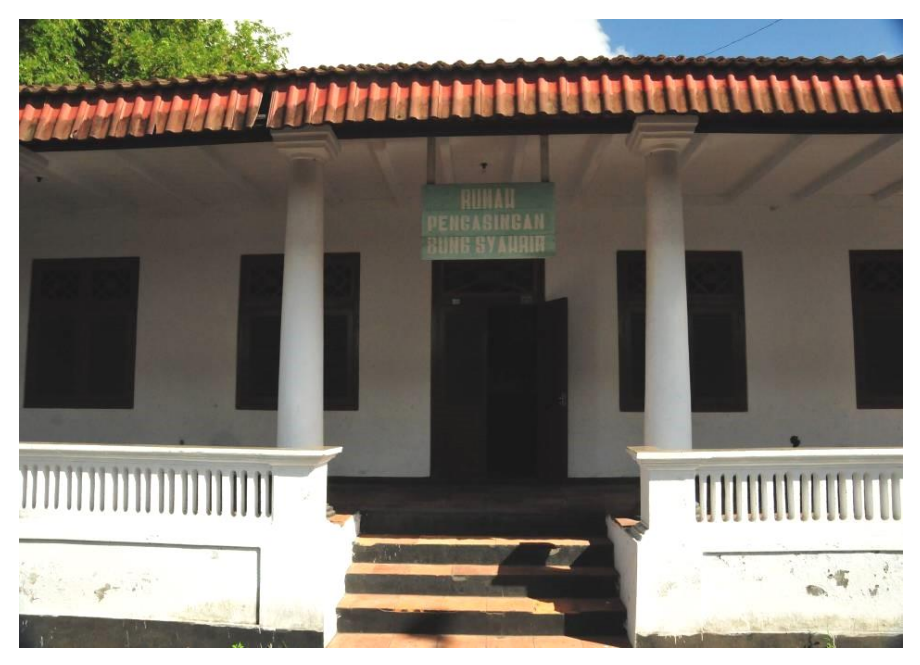

Sjahrir's House in Banda Naira

But after a few weeks, Sjahrir then moved to another house. He chose to live alone because he had many adopted children who sometimes bothered Hatta. Sjahrir's new home is about 1 kilometer from Hatta's house. The house is colonial style, has 4 pillars on the front porch, 1 door and 4 windows (see picture 4). Sjahrir's house was located in the Dutch office area, close to the former Captain Cole's British building in 1611.

Although he already has his own house, Sjahrir spends more time outside. He preferred to gather with young children, and of course also be familiar with their parents. Sjahrir was like their brother, and every time there were thanksgiving for Banda families, Sjahrir would have been invited (Anwar 2011).

The consistency of this attitude shows that Hatta and Sjahrir have principles in their life that always obey. Especially for Bung Hatta, the most obvious example can be seen is in his love of the books. Hatta really liked his books. Even since it was exiled in Digoel-Papua to Banda Naira, Hatta always brought along 14 book crates. But this love makes him very sensitive, e.g. he will be very disappointed if there are students who do not master the reading results, or will be very angry if there are folds (Ezel's Oren) in his books. Showing that, Hatta strongly emphasized the ability to reason in remembering and understanding a reading. The fold in the book, perhaps, shows the weaknesses of both reasoning abilities. 
Not only teaching, Hatta also gave an example of the importance of honesty as the main attitude. According to Des's story, when he was a child, he broken the window of Hatta's house because of the ball he kicked while playing in Hatta's yard. Hatta was very angry and then called Des and his friends to tell the truth what really happened. At first they were afraid to say the truth, but Hatta repeatedly advised by saying, "Unintelligence can be improved by learning, inexperience can be corrected by activities, but dishonesty is difficult to correct". Hearing that advice, Des finally confessed his mistake (interview with Des in 2010)

The principle which is also very valuable from Hatta is his willingness to always be present at the invitations of citizens' events in Banda. According to an informant, Hamadi Husain (Banda leader and also a close friend of Des Alwi), said that Hatta and Sjahrir (but more specifically Hatta) greatly appreciated the invitation of citizens to any event, large or small, luxurious or simple. Like a wedding, circumcision, or just a small family thanksgiving. Hatta, even always present early about 10 to 15 minutes before the event begins. But he will hurry home if the event is more than 10 to 15 minutes late (Hanafi 2013). The residents of Banda Naira have understood Hatta's behavior. So if anyone who wants to invite Bung Hatta to their event must start on time (interview with Hamadi in December 2018).

The life principles of Hatta and Sjahrir above are the evidence of their exemplary self-integrity in exile.

The terms of "national" and "nationalism" in Latin mean "born in". In Greek interpreted "ethnic" or "entity", which refers to culture, language, and descent outside the political context (Kanalana and Celepb 2011). The term nationalism is absorbed into Indonesian which has two meanings: first, about loving the nation and the State, and second, awareness of membership in a nation to jointly achieve, maintain, and perpetuate identity, integrity, for the prosperity and strength of the nation.

It was concluded that nationalism is a natural love of the motherland, triggered by an awareness that drives a group of people to unite and act in accordance with their cultural unity. The awareness to unite may be sourced from various views of life, ideology, and of course also religion. As Sukarno said in his article; "I am still nationalist, still Islamic, still Marxist. The synthesis of these 
Farid: Traces of The Socialist in Exile:

Mohammad Hatta And Sutan Sjahrir

three things fulfills my chest. One synthesis which, in my opinion, is a synthesis of geweldig". From Soekarno, we understand that Islam is not only able to combine harmony with nationalism, but even Islam becomes a booster of nationalism (Fossatia et al. 2020).

Hatta and Sjahrir's exemplary of nationalism was found in his efforts to introduce the history of Indonesia to his students in Banda Naira. In addition to teaching reading, writing, arithmetic and German, Hatta also gave additional lessons such as Indonesian history (Syahrul, Kurniawan, and Fadhila n.d.). The references are from the Malay-language Hamka books. Interestingly, according to Des, history lessons from Hatta are very different from history lessons from colonial teachers in Dutch schools. History of Indonesia is called by Hatta as the history of "the Indonesian nation", while in Dutch schools the lesson "History of the Motherland" is the history of the Netherlands itself. And figures such as Teuku Umar from Aceh, and prince Diponegoro from central Java, are always called villains and dissidents. Whereas by Hatta, these figures were national heroes because they dared to sacrifice their lives against the Dutch invaders (Alwi 2006).

But Hatta and Sjahrir were not the type of teachers who were content to teach with books, or felt sufficient in the classroom. Both are pedagogues who have similar characters who contribute to set an example in their daily lives. Hatta's example of nationalism is illustrated in a funny story told by Des in his book Bersama Hatta, Sjahrir, Tjipto dan Iwa K Sumantri, that one day Bung Hatta bought an orambai (small boat) from a fisherman in the village of Lonthoir. After being owned by Hatta, the boat was then painted in red and white. This is known by a Dutch police officer who immediately went to Hatta and protested it. Bung Hatta responded by asking, "What is the color of the Dutch flag?" The police replied, red, white, and blue ". Bung Hatta replied, "yes it is red, and white, then the blue color of the sea". The police was silent as if it was difficult to reject Hatta's logic (Alwi 2006).

Hatta's way of introducing the red and white colors for the Banda children was a manifestation of Hatta's love for the country which he symbolized in red and white as Indonesia's identity. And it was proven later on, that Red and White became the color of the pride of the flag of an independent Indonesian nation state. 
Sjahrir also has an example of the same nationalism. In the same book, Des 2002 also tells, that ones time Sjahrir also really wanted to have a boat, like Hatta, who already had a small arumbai. Sjahrir then bought a boat from a ship craftsman in Lontor. He ordered a bigger one than Hatta's, modified like a European yacht. One day Sjahrir wanted to give the name of his boat. The children who always played with him proposed name "volcano", which is the active volcano on Banda Naira. Others proposed "Banda Besar", the largest island in the Banda Naira archipelago. There were also who suggested the names of fish. Others proposed name "Amsterdam", and also "Sumatra".

Specifically the name Sumatra, Sjahrir immediately refused, even though he was from there. For a moment he thought and then said, I chose the name "Indonesia". Some children were confused because they had never heard that name in Dutch schools, except Des and Tjipto's children who had long been close to exiles. Sjahrir explained, that name will never be taught in Dutch schools, because they hate it. That name is the same as Tiongkok for the Chinese. The Dutch prefer to call it Indie or the Dutch East Indies. But we call it Indonesia.

If Hatta introduces his love for this nation with a red-and-white symbol, then Sjahrir even more assertive in introducing the name of "Indonesia" to Banda children who still don't know what that name is. A very risky action, because of that name, Sjahrir was exiled to Digul and Banda. Sjahrir was never afraid to echo the name of "Indonesia" for his love and longing the independence of this nation. Sjahrir even always teaches Banda children to spell verses of the Indonesia Raya song during he outing with his friends on a kole-kole boat (see picture 5), or moments of their picnic to the coast of Pisang Island on weekends (Alwi 2006). The island that has been renamed become "Sjahrir Island" today. 
Figure 5

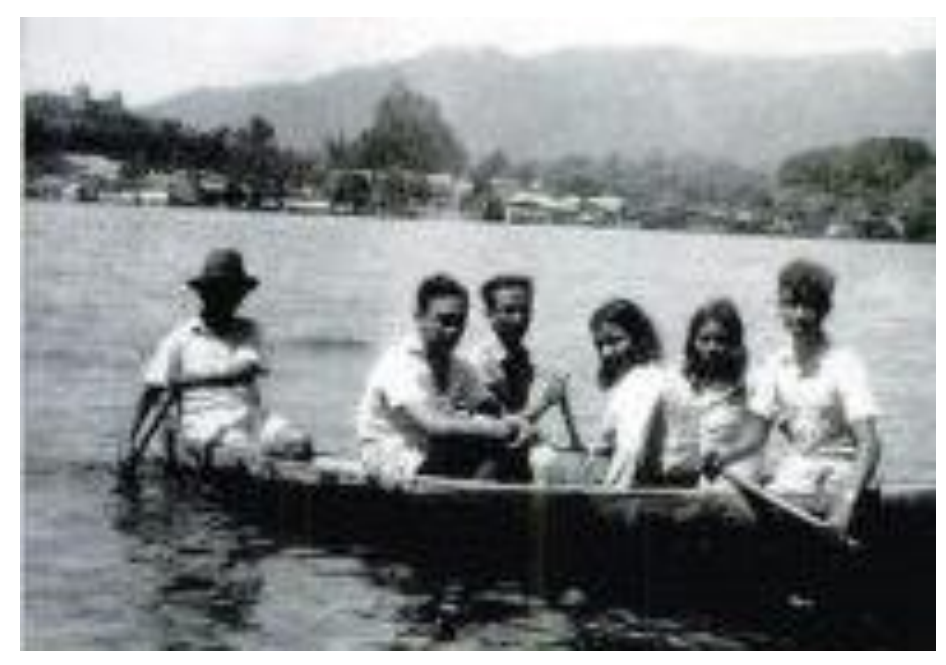

Sjahrir and friends on a "kole-kole" boat

Another interesting example was told by an informant from Tanarata Village (Naira Island), that there was a charcoal seller from Gunung Api who was imprisoned by the Dutch. His name is Bapak La Saoda. When Bung Hatta arrived in Banda, Mr. La Saoda had become a prisoner in a Dutch prison located next to Hatta's house. One afternoon, when Hatta was sitting enjoying coffee, he saw La Saoda coming out of the prison and then passing the front of his house with a bag of trash. La Saoda caught Hatta's attention. One time Bung Hatta tried to call him and there was a brief conversation. Bung Hatta asked, "who are you?" He replied, "I am La Saoda". "It seems you are a good person, why did you go to jail?" Asked Hatta. La Saoda replied, "because I don't like invaders". Since the conversation made them both very familiar.

La Saoda is also familiar with other political prisoner figures. He then became a kind of "secret informant" among the political prisoners. The Dutch never suspected that the basket of charcoal he used turned out to be a place to store secret papers between political exiles. One important letter that he had kept was the plan to move Hatta and Sjahrir to Java someday.

When European nations were hit by a political crisis. Where Japanese fascism is getting stronger. Break the Pacific war. The Netherlands then ordered to secure its political prisoners in Banda Naira. Including Hatta and Sutan Sjahrir. Both were then picked up by two American pilots to a small plane that was 
anchored in the bay of the front of the palace. This part of the story is told by Sjahrir in his book Out of Exile (Dec 2002; Sjahrir 1949).

Before going to Java, Hatta met La Saoda. Hatta then left a lodong (a bamboo stick to fill water) and telling Saoda not to open this bamboo before Hatta arrived in Java. After receiving news that Hatta had arrived in Java, La Saoda opened the contents of the bamboo which turned out to be a red and white flag (Kusno 2012).

The meaning of hatta-sjahrir exemplary values for the banda naira. In phenomenology, meaning is not the meaning of something, but all the spark of everyday life, all events that occur in the life-world. The life-world is a human world that is experienced in awareness, in the actions of cognition and perception, and how they obtain value or esthetically valued.

Even though Hatta and Sjahrir had pass away, the examples reside in the stock of knowledge of the citizens in Banda Naira to this day. One that can be analyzed is the Sekolah Sore created by Hatta and Sjahrir for the education of Banda native children. This Sekolah Sore made an impression on the memory of Banda Naira individuals to perceive the frame of reference or orientation which then made it easier for them to interpret the events taking place in their lives today.

The results of the interpretation created two universities in Banda Naira at this time, namely; The College of Fisheries and STKIP (see picture 6), which is an initiative of Des Alwi (Hatta and Sjahrir's adopted son) and Hamadi Husain (Des's best friend), and with support from the entire community of Banda Naira in a joint forum in 2000 ago. This shows, that in the "knowledge memory" of the Banda people, two national figures are inherent and unforgettable. So through the agreement of all the citizens of Banda, they chose the name Hatta-Sjahrir as the name of the two campuses to be remembered. 
Figure 6

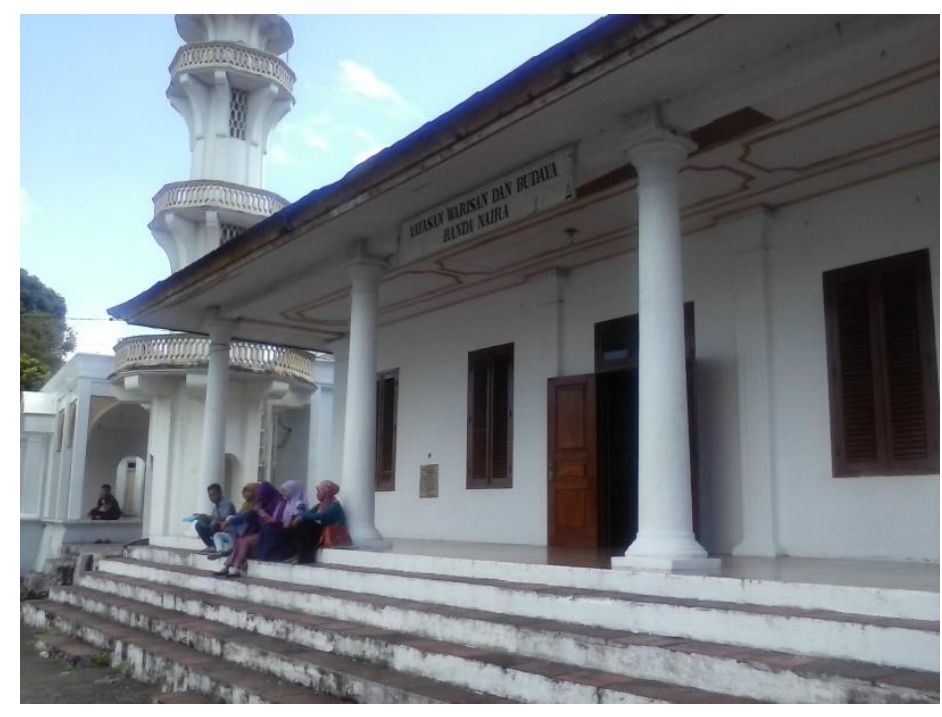

The College of Hatta-Sjahrir under the Foundation of Yayasan Warisan Budaya Banda Naira

Both campuses later became a place for Hatta and Sjahrir's cadre to continue. This is in line with the concept of regeneration of Hatta, which fully means education. Hatta said, "Cadreization is the same as education, and not politics!" Hatta wrote in 1932. The task of the next leader is to educate the people, namely the ability to explore people's feelings and thoughts and provide inspiration so that peopke can be saved from difficulties and burdens. For this reason, the educational foundation of cadre leaders is "nationality and people". To build a national spirit in an independent nation is to build its humanity.

The Sekolah Sore heritage in the past, and the Hatta-Sjahrir College today shows the existence of a bridge of civilization that connects the generation of Hatta and Sjahrir as predecessors, with the Des Alwi generation or those who are contemporaries, and also at the same time with today's generation of students as its successors. In this process, the typification of knowledge continues and builds upon their experiences, even though these generations have never met each other.

The examples of substantive-religious attitudes of Hatta and Sjahrir were also well inherited by the people of Banda Naira. As evidence, that there is no one statue or monument to commemorate both. Indeed, Hatta had suggested to Des, if he wanted to remember it, then build a mosque for the society. Bandanese finally built a mosque which was also named Hatta-Sjahrir. Besides the mosque, they also only left books, photographs, Hatta's typewriter, and Sjahrir's gramophone. 
Mosque as a memory is also included in the principle of Hatta regeneration. Because for Hatta, the main thing about cadre education is to shape character and strengthen faith. That means, regeneration is not just a matter of intellectual intelligence, but the main thing is also the moral footing of enlightened religion.

The example of nationalism from Hatta and Sjahrir to the Banda children was aimed at building a great personality as an independent individual, not as a sycophant, or a person who bowed to power, or who prided himself on his homeland (ethnocentric). Hatta, who introduced red and white in his Arumbai, and Sjahrir who asked his children to write the name "Indonesia" on his boat, actually gave a message about the meaning of freedom, and was against feudalism. This thought, according to John Legge, represents a moral and political flow originating from the values of our nation's life, which fights for human dignity, human dignity with all its joys and sorrows (Legge 1993).

In history, perhaps only a few national figures consistently fought for the dignity of the nation until the end of its life. Hatta and Sjahrir are one of them. Although both are not the most influential (as Bung Karno), but the combination of Hatta-Sjahrir has laid the foundations of struggle and an amazing education, which became an example for anyone, not only to Banda children, but also to the children of Indonesian nation. The relationship between religion and politics is explored from a theoretical standpoint, assuming that religious clerics can be coopted by the ruler acting as an autocrat (Auriola and Platteaub 2017).

\section{CONCLUSION}

Mohammad Hatta and Sutan Sjahrir are warriors and educators who set an example through the narratives of their everyday lives. In Digul-Papua, Hatta and Sjahrir struggle and taught about the meaning of sacrifice and survival in the land of waste. In Banda Naira, Hatta set an exemplary of substantive religious-ethical, self-integrity, and nationalism values. Their ethical-religious values appear in principles that are shared, they appear in simple lifestyle, the ability to balance spiritual and worldly needs, and also care to always help the poor. Hatta known by the people of Banda as a very simple and unpretentious figure, and Sjahrir remembered as someone who has a high concern for helping difficult people. The values of integrity appear in their discipline of time, honesty, and respectfull to others regardless of their social status. Hatta was very well known as "walking 
Farid: Traces of The Socialist in Exile:

Mohammad Hatta And Sutan Sjahrir

hours" because of his discipline, while Sjahrir known as a figure who very close to the hearts of the citizens of Banda. They called him "pokrol bamboo", or defender of the people. While the values of nationalism appear in their courage to fight colonialism in a pedagogical and symbolic way. The pedagogical way is resistance through the education route, by exposing the historical truth about the nation's heroes who were considered enemies by the Dutch invaders. The symbolic way is resistance by introducing signs (symbols) such as the color of the flag and the name of Indonesia as a sign of the identity of an independent Indonesian nation. Hatta and Sjahrir have proven themselves not to be just socialist figures because they both bearer thought of socialism, but at the same time succeeded in giving their exemplary and alignments to people for the realization of advanced, and independent people. The exemplary of Hatta-Sjahrir are like an oasis for the Indonesian people who yearn for a religious person, has integrity, independent, and loves the motherland.

\section{REFERENCES}

Akira, Oriah and Senian Malie. 2012. "Integrity Dimensions and Religious Orientation in Aspect of Employees Job Conduct: An Exploratory Model Building." Procedia Journal - Social and Behavioral Sciences 62:167-74.

Al-Aidaros, Al-Hasan, Faridahwati Shamsudin, and Kamil Md. Mohd. Idris. 2013. "Ethics and Ethical Theories from Islamic Perspective." International Journal of Islamic Thought 4.

Alwi, Des. 2006. Sejarah Banda Naira. Malang: Pustaka Bayan.

Anwar, Rosihan. 2011. "Sutan Sjahrir: Negarawan Humanis, Demokrat Sejati Yang Mendahului Zamannya.” PT Kompas Media Nusantara.

Auriola, Emmanuelle and Jean-Philippe Platteaub. 2017. "Religious Co-Option in Autocracy: A Theory Inspired by History." Journal of Development Economics 127:395-412.

Bijl, P. A. 2017. "Human Rights and Anticolonial Nationalism in Sjahrir's Indonesian Contemplations." Journal of Law \& Literature 29(2).

Borng, Kwong. 2002. "Toward a Theoretical Framework for Understanding the Relationship between Situated Action and Planned Action Models of Behavior in Information Retrieval Contexts: Contributions from Phenomenology." Journal Information Processing \& Management 38(5):613-26. 
Chan, Eugene Y. and Jasmina Ilicic. 2019. "Political Ideology and Brand Attachment." International Journal of Research in Marketing 36(4):630-46.

Chuaha, Swee-Hoon, Robert Hoffmanna, Bala Ramasamy, and Jonathan H. W. Tan. 2014. "Religion, Ethnicity and Cooperation: An Experimental Study." Journal of Economic Psychology 45:33-43.

El-Torky, Assem A. 2018. "Political Symbolism in Mohammad Ali's Mosque: Embodying Political Ideology in Architecture." Alexandria Engineering Journal 57(4):3873-80.

Fossatia, Diego, Edward Aspinallb, Burhanuddin Muhtadic, and Eve Warburtond. 2020. "Ideological Representation in Clientelistic Democracies: The Indonesian Case." Electoral Studies Journal 63.

Gea, A. A. 2016. "Integritas Diri: Keunggulan Pribadi Tangguh." Character Building Journal 16-26.

Hanafi, Muhammad. 2013. "Kedudukan Musyawarah Dan Demokrasi Di Indonesia." Jurnal Cita Hukum, UIN Syarif Hidayatullah 1(2).

Harisa, L. T. 2011. Hubungan Antara Moral Integrity Dengan Spiritual WellBeing Pada Santri Mu'allimien Pesantren Persatuan Islam No. 3 Pameungpeuk. Bandung: UIN Sunan Gunung Djati.

Hatta, Mohammad. 2011. Menuju Gerbang Kemerdekaan: Untuk Negeriku, Sebuah Otobiografi. Jakarta: . PT Kompas Media Nusantara.

Kanalana, Ender and Cevat Celepb. 2011. "A Glance to Education in the Middle East under the Shadow of Politic and Ethnic Conflicts in the Region." Procedia Journal - Social and Behavioral Sciences 15:2864-68.

Kuenzi, Michelle. 2018. "Education, Religious Trust, and Ethnicity: The Case of Senegal." Journal of Development 62:254-63.

Kusno, Malikul. 2012. "Bung Hatta, Dari Era Kolonial Hingga Orde Baru: Sebuah Refleksi (Artikel).” Jurnal Konfrontasi 1(1).

Legge, J. 1993. Kaum Intelektual Dan Perjuangan Kemerdekaan: Peran Kelompok Sjahrir (Terj. Hasan Basari). Jakarta: Pustaka Utama Grafit.

Miller, Michelle Ann. 2010. "Reviewed Work: Friends and Exiles: A Memoir of the Nutmeg and the Indonesian Nationalist Movement by Des Alwi, Barbara S. Harvey." Pacific Affairs Journal 83(4).

Mohammed, A. 2011. "The Role of Yemeni Accountants in Fighting Corruption." The Legal Accountant 15(9):30-37.

Murphy, John W. 1986. "Phenomenological Social Science: Research in the Public Interest.” The Social Science Journal 23(3):327-43. 
Rose, Marvis. 2010. Indonesian Free: A Political Biography of Mohammad Hatta (Terj.). Jakarta: Gramedia.

Straßheim, Jan. 2010. "Relevance Theories of Communication: Alfred Schutz in Dialogue with Sperber and Wilson." Journal of Pragmatics 42(5):1412-41.

Syahrul, M., Aris Kurniawan, and Esty Fadhila. n.d. "Mengenalkan Sejarah Rempah Di Banda Naira Melalui E-Book Jurnal Fotografi." Jurnal Rekamakna.

Veer, K. van der. 2003. "The Future of Western Societies: Multicultural Identity or Extreme Nationalism?" Futures Journal 35(2):169-87. 